\title{
Institute Role of Teachers' Education in Improving the Standard of Development Achievement Rate and Standard of Teacher and Education Personnels of Early Childhood Education
}

\author{
Syahrial Bakhtiar \\ Faculty of Sport Sciences \\ Universitas Negeri Padang \\ Padang, Indonesia \\ Syal_fik@yahoo.com
}

\author{
Ruri Famelia \\ Faculty of Sport Sciences \\ Universitas Negeri Padang \\ Padang, Indonesia
}

\begin{abstract}
Understanding the importance of the education during the early age, the Indonesian government supports the Early Childhood Education (ECE) through Permendiknas 58 Year 2009 on Standards of ECE. This standard include a) The standard of development achievement rate, b) The standard of teachers and education personnel's, c) The standards of content, process, and assessment; and d) The standard of facilities and infrastructure, management, and financing. This paper aims to evaluate the inconsistencies between standard of development achievement rate and the standards of teachers and education personnel's, especially in the competence of motor skills that should be achieved by young children in accordance with the competencies of teachers in teaching it. Furthermore, this paper describes the role of teacher education institution (Lembaga Pendidik Tenaga Kependidikan-LPTK) in preparing candidates for early childhood teachers in meeting the competencies standards of teachers and education personnel, according to Permendiknas number 58 year 2009.
\end{abstract}

Keywords-early childhood education; the standards of development achievement rate; the standards of teachers; motor competence; teacher education institution

\section{INTRODUCTION}

Research finding shows that the beginning phase of a child has great impact in their adult age [1][2]. Concerning with how crucial the age is, the early childhood education plays the pivotal role in establishing children's character and development in long and short term[3][4][5][6]. The government of Indonesia has showed their commitment in supporting early childhood education by establishing the Standard of Early Childhood Education (ECE) through Regulation of Ministry of National Education - UU No. 58 Year 2009. The regulation consists of a) Standard of development achievement rate, b) standard of teachers and education personnel, c) standard of content, process and assessment, and d) standard of facilities and infrastructure, management and financial. The four standards must be comprehensive and supportive. However, it is still found that there are inconsistencies among the standards. One of the inconsistencies can be seen from the motor skill standard on children's development achievement rate and competency standard of the teachers and education personnel.

A pilot project conducted with the assistant from the World Bank and the Netherland government developed community based early childhood education as a platform to educate early childhood children in Indonesia[7][8][9]. This pilot showed that Indonesian children performed poor in lots of development domains, including physical health and motor skills[7][8][9][10]. In general, in UU No. 58 Year 2009, motor skill standard consists of gross motor skill (e.g. running, jumping, throwing, hopping, catching, kicking) and fine motor skill (e.g. folding, cutting papers, drawing and patching appropriate pictures). Another preliminary study in ECE centers in Padang city shows that children at age $3-5$ years showed low competence on their fundamental motor skills[11][12].

In addition UU No. 58 Year 2009 established the standard of teachers and education personnel describes academic qualification and standard of competencies required for teachers and education personnel of ECE center. One competency that teachers should acquire is understanding children's motor development (gross motor skills and fine motor skills). However, it was found that early childhood teachers in Indonesia were poor in their competencies[13][14] and lack understanding of children motor skills and the pedagogy in teaching motor skills for young children[11]. Therefore, strategic plan to improve teachers' competencies is needed[15].

Thus, the primary aim of this paper was to describe the inconsistencies on motor standard in development achievement rate and standard of teachers and education personnel. The secondary aim was to propose strategic plans to improve early childhood teachers' competency in fundamental motor skills and pedagogy in teaching motor skills for young children. 


\section{LITERATURE REVIEW AND DISCUSSION}

\section{A. DEFINISION OF MOTOR SKILLS IN UU NO. 58 YEAR 2009}

One major concern in motor skill standard is the term using in the UU No. 58 Year 2009. This ministry regulation uses the term of "gross motor skills" to describe running, hopping, catching and striking skills. Yet, those skills are more appropriate described as Fundamental Motor Skills. Fundamental motor skills are classified into two categories, namely locomotors skills and object control skills[16]. Locomotors skills refer to the ability to move the body to one point to another (e.g. running, jumping, hopping, galloping, sliding, leaping, and skipping) and object control skills refer to the ability to manipulate with hands or feet (e.g. kicking, catching, throwing, and striking)[16]. While, gross motor skills refer to simple movement that involve group of large muscle [16], for instance walking, and moving arms. The using of inappropriate terms in UU No.58 year 2009 could lead to the misunderstanding of the standards that need to be achieved by children and standards that need to be mastered by teachers.

Experts describe the importance of children's fundamental motor skills development through fundamental motor development model. There are three models describe the importance of fundamental motor skills. The first model is The Sequential Model of Motor Development[17], known as Seefeldt model. Seefeldt explains that the fundamental motor skills should be mastered in early childhood. If children cannot master those skills, they will not be able to break proficiency barrier, to develop more advance motor skills. Second model is the "Mountain of Motor Development" Model[18], introduced by Clarke \& Metclafe. This model explains that every child is unique in motor skill development, in which every individual will master some motor skills than other skills. This uniqueness will determine their preference on type of physical activity/game. For example, those who master kicking a ball may prefer to play soccer as their favorite game. The third model is Gallahue's Hourglass Model[16], which combines the Seefeldt Model with both internal and external factors of fundamental motor development. This model explains that the children's motor development is influenced by individual ability, genetic and the environment.

Based on the three models, the experts of children's fundamental motor development conducted some studies and concluded that the children fundamental motor skill will not develop along with the maturation, yet it requires wellstructured instruction programs that give children the opportunities to practice their motor skills and receive feedbacks from the instructors[16][19][20]. The concept is in line with the Piaget's cognitive development theory[21], in which every early age children needs to explore their body in learning process. Thus, ECE centers in Indonesia are not able to develop children's fundamental motor skills development as children is more passive and focus on the mastery of academic content[10]. Moreover, the lack of teachers' understanding toward the fundamental motor skills development and the teaching methods in motor skill instruction[11] plays crucial roles that cause the issues.

The three models of children's fundamental motor skills development are the main bases that bridge the development of fundamental motor skills to more complex development. We might think that the fundamental motor skills are not required in daily activities, yet the misconception is argued by the three models.

\section{B. TEACHING METHODS IN MOTOR SKILL INSTRUCTION}

The locomotors and object control skills are developed through some stages. Generally, there are three to five stages of the development[16]. The distinction is based on the motor complexity, for instance, catching a ball has five stages, and galloping has three development stages. The stages are not linear that it means the development of children can randomly jump from the first stage to the third one, then move backward to the second stage[16]. The understanding related to the motor development stages will enable the teachers to teach the fundamental motor skills[22]. For instance, when children are catching a ball, it seems that they catch it with similar ways. When the ball is caught, then the teachers assume that they are able to perform the task. However, when we observe the detail we may find a child catches the ball with his hand, the other might catch it with their arms or the ball can be caught while a child standing still or moving. The situation describes the different stages of motor skills development in catching a thing.

The understanding of these stages will enable teachers to teach fundamental motor skills to the children. Those children who are already on the second or third stage can be trained with big light ball and eventually develop their skills by using smaller ball for the next stage. The method might enable the children to develop their fine motor skills before catching a smaller ball by using their hand. Further, those who are already in the fourth stage mean that they are able to catch the ball with their hand in stationary position. Teachers are expected to give proper instruction to promote children to improve to the next stage, which is catching while moving. This method is not merely able to improve their ability in catching a ball but also to improve their coordination ability, which includes in standard of motor skill achievement in the regulation of Ministry of National Education UU No.58 Year 2009.

\section{INSTITUTE ROLES OF TEACHERS' EDUCATION IN SUPPORTING THE REGULATION OF MINISTRY OF NATIONAL EDUCATION UU NO.58 YEAR 2009}

The previous discussion describes the inconsistencies of standard of development achiement rates and competencies standar of ECE teachers. Understanding of children motor development as an element of holistic development implies the responsibilities of institute of teachers'education to prepare the ECE teachers to be competent educators. The institute is responsible to introduce fundamental motor skill to the novice children during their training[22]. The introduction is not merely focused on the theory, but also the practice in the 
classroom. Fundamental motor skills is subject requiring physical movement, thus the novice teachers should be able to practice the movement during their training as well as their real classroom.

Referring to other countries, like the USA, have National Guidelines for Physical Activities of Early Childhood[23], in which vividly states that "providing the chance the children to perform physical activities to improve their competence in fundamental motor skills". Thus, ECE teachers in the USA possess competencies in fundamental motor skills, that they are able to deliver structured program in preschools or in childcare center.

Besides introducing the theory and practice related to fundamental motor skills and the teaching methods, the institute of teachers' education is expected to conduct researches related to children fundamental motor skills as the current theory are mostly found and obtaines in developed countries in America, Europe and Australia. As the concept proposed in Hourglass Model states that the development of children fundamental motor skills is influenced by genetic and environment, the research for the Indonesian children and the environment will support the relevant children motor skills development with the condition of Indonesian children. Further, by conducting the active researches in the institute, it is expected that the national guidelines of physical activities for Indonesian children can be established.

\section{CONCLUSION}

The commitment of Indonesian government in supporting the implementation of ECE program is performed in many ways. One of those is the pilot project funded by the World Bank and the Netherland government in stipulating the government regulation supporting the implementation of ECE program in all over Indonesia. Recently, the regulation of Ministry of National Education UU No. 58 Year 2009 becomes the national reference for the implementation of both formal and informal ECE program in Indonesia. However, there is still inconsistency in the implementation, namely the standard of children development rates and competencies standard of ECE teachers, particularly in motor skills competencies. The condition becomes an issue that children motor skills competences are low. The issue is caused by the teachers' insufficient understanding of children motor development theory and practice as well as the teaching methods. Thus, the institute of teachers' education is expected to introduce the theory and practice of fundamental motor skills to the ECE novice teachers. Further, the institute is also responsible to conduct researches related to Indonesian children's motoric skill development to support holistic ECE program.

\section{References}

C. Hertzman and T. Boyce, "How experience gets under the skin to create gradients in developmental health," Annu. Rev. Public Health, vol. 31, pp. 329-347, 2010. early childhood education and care, and child outcomes," Australas. J. Early Child., p. 42,1,49-59, 2017.

[3] K. Burger, "How does early childhood care and education affect cognitive development? An international review of the effects of early interventions for children from different social backgrounds," Early Child. Res. Q., vol. 25, no. 2, pp. 140-165, 2010.

[4] L. Bakken, N. Brown, and B. Downing, "Early Childhood Education: The Long-Term Benefits," J. Res. Child. Educ., vol. 31, no. 2, pp. 255-269, 2017.

[5] A. Cortázar, "Long-term effects of public early childhood education on academic achievement in Chile," Early Child. Res. Q., vol. 32, pp. 13-22, 2015.

[6] R. Hahn et al., "The Guide to Community Preventive Services Review of Interventions to Promote Health Equity in the United States," J. Health Dispar. Res. Pract., vol. 9, no. 6, p. 2, 2016.

[7] A. Hasan, M. Hyson, and M. C. Chang, Early childhood education and development in poor villages of Indonesia: Strong foundations, later success. World Bank Publications, 2013.

[8] A. B. P. Hasan and E. Suwarni, "Policies and practices for promoting multicultural awareness of indigenous early childhood education in indonesia," Int. J. Child Care Educ. Policy, vol. 6, no. 1, pp. 63-94, 2012.

[9] H. Alatas et al., "Early childhood education and development services in Indonesia," Institute of Southeast Asian Studies (ISEAS), 2013.

[10] J. P. Singh, United Nations Educational, Scientific, and Cultural Organization (UNESCO): creating norms for a complex world. Routledge, 2010.

[11] \& R. M. R. Famelia, J. Goodway, J, S. Bakhtiar, "Investigating the Motor Competence and Physical Activity of Indonesian, Muslim Preschoolers from Urban and Rural Areas.," J. Sport Exerc. Psychol., pp. S63-S64.

[12] S. Bakhtiar, "Fundamental motor skill among 6-year-old children in Padang, West Sumatera, Indonesia," Asian Soc. Sci., vol. 10, no. 5, pp. 155-158, 2014.

[13] Y. Yusria, "Pemberdayaan Pendidikan Anak Usia Dini Melalui Standar Kompetensi," Media Akad., vol. 27, no. 3, 2012.

[14] K. KOORDINATOR and B. P. M. D. A. N. KEBUDAYAAN, "Hasil Pengkajian Kompetensi Pendidik Paud Tentang Kemampuan dalam Pendidikan Karakter pada Anak Usia Dini.,

[15] F. E. Aboud, K. Proulx, and Z. Asrilla, "An impact evaluation of Plan Indonesia's early childhood program," Can J Public Heal., vol. 107, no. 4-5, pp. 366-372, 2016.

[16] D. L. Gallahue and J. C. Ozmun, Understanding motor development: Infants, children, adolescents, adults. McGraw-Hill Humanities, Social Sciences \& World Languages, 1998.

[17] V. Seefeldt, "The concept of readiness applied to motor skill acquisition," Child. Sport, pp. 31-37, 1982.

[18] J. E. Clark and J. S. Metcalfe, "The mountain of motor development: A metaphor," Mot. Dev. Res. Rev., vol. 2, no. 163190, 2002.

[19] D. F. Stodden et al., "A developmental perspective on the role of 
motor skill competence in physical activity: An emergent relationship," Quest, vol. 60, no. 2, pp. 290-306, 2008.

[20] J. D. Goodway, R. Famelia, and S. Bakhtiar, "Future directions in physical education \& sport: developing fundamental motor competence in the early years is paramount to lifelong physical activity," Asian Soc. Sci., vol. 10, no. 5, p. 44, 2014.

[21] B. J. Wadsworth, Piaget's theory of cognitive and affective development: Foundations of constructivism. Longman Publishing, 1996.

[22] S. Bakhtiar, "The implementation of dynamic system theory and the principles of growth in physical education of elementary school," Asian Soc. Sci., vol. 9, no. 12, p. 105, 2013.

[23] J. E. Clark et al., Active Start: A Statement of Physical Activity Guidelines for Children Birth to Five Years. ERIC, 2002. 